\title{
THE CHANGES IN THE DISTRIBUTION OF BODY WATER ACCOMPANYING INCREASE AND DECREASE IN EXTRACELLULAR ELECTROLYTE
}

\author{
By DANIEL C. DARROW AND HERMAN YANNET
}

(From the Department of Pediatrics, Yale University Medical School, New Haven)

(Received for publication November 21, 1934)

Considerable attention has been given the relation of body water to the metabolism of fixed base. Gamble, Ross and Tisdall (1) have pointed out that loss or gain of sodium is usually accompanied by an increase or decrease in extracellular water sufficient to keep the extracellular sodium constant in concentration. Furthermore, since nearly all of the potassium of the body is intracellular and variations in the concentration of potassium in serum are relatively small, a loss or gain in potassium is usually accompanied by an increase or decrease in cellular water sufficient to keep the osmotic pressure of cellular fluid in equilibrium with that of blood plasma. These authors have estimated the probable loss of water from intracellular and extracellular spaces which accompanies the losses of sodium and potassium during starvation. Gamble, Blackfan and Hamilton (2) have described the probable mechanism of the diuretic effect of acidifying salts by similar reasoning. Analogous studies have been made in diabetic coma (3) and infantile diarrhea (4). Since such studies are based on the premise of a parallel loss of water and electrolyte, they do not take into account the redistribution of body water which must take place when electrolyte is lost or gained without a corresponding loss or gain in water. The present study describes the changes in concentration of water and electrolyte in serum and erythrocytes when the amount of extracellular electrolytes is altered with little change in total body water. The probable shifts of body water which explain these changes are discussed.

The experimental procedure used to produce variation in extracellular electrolyte without significant alteration in total body water is based on experiments described by Schechter, Cary, Carpentieri and Darrow (5). These experiments demonstrated that when a watery solution was placed in the peritoneal cavity, it tended to assume the composition of a fluid in ionic and osmotic equilibrium with blood plasma. Thus when "isotonic glucose solution" ( 5 per cent) was placed in the peritoneal cavity, sodium, chloride, and bicarbonate diffused into the fluid while glucose diffused into the blood. At first the rate of diffusion of electrolyte into the peritoneal fluid was so rapid that water also passed into the peritoneal cavity. However, after four to six hours the amount of fluid in the peritoneal cavity was approximately that injected, but the composition approached that of a fluid in equilibrium with plasma. In guinea pigs about twenty-four hours was required for complete absorption; the interval in dogs, monkeys and rabbits was not determined, but is probably between twelve and twenty-four hours. Since the fluid in the peritoneal cavity was not immediately available throughout the tissues, the body may be considered to have lost temporarily the amount of electrolyte present in the peritoneal cavity, while the total amount of body water remained relatively unaltered. The interpretation of the results is simplified by the fact that anuria accompanies these experiments and the only loss of water is by evaporation and the only gain, from cellular oxidations, which for the present purposes could be neglected.

In order to increase the amount of extracellular electrolyte, saline of double physiological strength (1.8 per cent $\mathrm{NaCl}$ ) was injected into the peritoneal cavity. In these experiments after about four hours, the fluid in the peritoneal cavity was in approximate equilibrium with the blood plasma and the total volume was approximately that injected. In this case the total amount of extracellular electrolyte was increased with relatively small change in total body water.

\section{EXPERIMENTAL PROCEDURE}

Healthy dogs, rabbits and monkeys (Macacus rhesus), maintained on an adequate diet, were used as the experimental animals. The last feeding occurred about eighteen hours before the experimental procedure. Food and water were removed from the cages during the course of the experiments. 
Blood specimens (about $30 \mathrm{cc}$. in dogs and $20 \mathrm{cc}$. in rabbits and monkeys) were taken from the external jugular vein in dogs, directly from the heart in rabbits and from the femoral vein in monkeys. About $10 \mathrm{cc}$. of the blood were immediately transferred to a tube containing a small amount of mercury and securely stoppered. The size of the tube and the amount of mercury used were such that the blood completely filled the tube. Defibrination was accomplished by gentle inversion of the stoppered tube for about five minutes. The remainder of the blood was delivered under mineral oil, allowed to clot at room temperature, centrifuged and the clear serum removed.

Soon after withdrawal of the first specimen of blood, a five per cent solution of glucose was injected into the peritoneal cavity in one series of animals. The glucose solution was freshly prepared and sterile, and the amounts injected were approximately $100 \mathrm{cc}$. per $\mathrm{kgm}$. of body weight in most of the experiments. The second series of animals received similar quantities of freshly prepared, sterile 1.8 per cent solution of sodium chloride intraperitoneally. In both cases the solutions were warmed to body temperature before injection and gave no evidence of being irritating. In the experiments on dogs the urine was collected in cages equipped for metabolic studies. In the experiments on rabbits and monkeys clean dry pans were placed under the wire cages. About four to six hours later, a second specimen of blood was obtained and treated in the same way as the first specimen. Samples of the peritoneal fluid were obtained at this time in the dogs, but in the monkeys and rabbits it was usually impossible to obtain peritoneal fluid without killing the animals and this was deemed unnecessary in most of the experiments.

In order to determine the amount of fluid remaining in the peritoneal cavity after approximate equilibrium had been established, fourteen animals were sacrificed and the peritoneal fluid drained and measured. These animals were also carefully examined for gross pathological changes. In four of the animals a measure of the total volume of material in the gastro-intestinal tract was made. No histological studies were carried out.

\section{CHEMICAL METHODS}

The volume of the blood cells was determined on the defibrinated blood by centrifuging at high speed for 20 minutes in capillary tubes. Measurements of the heights of the columns of blood and cells were made with calipers. The following chemical determinations were made: protein, by macro-Kjeldahl (6) method using superoxol to insure complete digestion; sodium, by Butler and Tuthill's modification of the method of Barber and Kolthoff (7), without removal of phosphate on serum but with removal of phosphate on whole blood; chloride, by Patterson's ( 8 ) method, using $0.5 \mathrm{cc}$. samples; water, by weighing before and after drying overnight at a temperature of $105^{\circ} \mathrm{C}$. All determinations were made in duplicate. The concentrations in the cells were calculated from the hematocrit values and the con- centrations in whole blood and serum by the following formula: $C=\frac{B-S(1-V)}{V}$, where $C$ represents cell concentration; $\mathrm{B}$, whole blood concentration; S, serum concentration and $\mathrm{V}$, the proportion of red cells in whole blood.

\section{EXPERIMENTAL RESULTS}

During the course of the experiments, data were collected which permitted estimation of the changes in concentration of electrolyte and water in serum and erythrocytes. The present paper presents such data as bear on the probable changes in distribution of water produced by the experiments. In a second paper (14) the changes in the concentration of electrolytes and water in erythrocytes will be discussed. Mention of the latter findings will be made in the present paper only inasmuch as the changes found in this accessible cell are used to explain the clinical symptoms of the animals and the probable changes in distribution of water in the body.

\section{A. Amount of fluid remaining in the peritoneal cavity}

Table I shows the amount of fluid recovered at autopsy after a lapse of time comparable to that

TABLE I

Volume of fluid remaining in the peritoneal cavity

\begin{tabular}{l|c|c|c|c|c|c|c}
\hline \hline Animal & $\begin{array}{c}\text { Experi- } \\
\text { ment } \\
\text { num- } \\
\text { ber }\end{array}$ & Weight & $\begin{array}{c}\text { Solution } \\
\text { injected }\end{array}$ & $\begin{array}{c}\text { Amount } \\
\text { injected }\end{array}$ & $\begin{array}{c}\text { Amount } \\
\text { recov- } \\
\text { ered }\end{array}$ & $\begin{array}{c}\text { Time } \\
\text { elapsed }\end{array}$ & Urine \\
\hline & & kgm. & & $c c$. & $c c$. & hours & $c c$. \\
Dog 1... & 1 & 6.4 & Glucose & 500 & 467 & 6.0 & 5 \\
Dog 6... & 16 & 6.6 & Glucose & 500 & 587 & 5.0 & 8 \\
Dog 3... & 7 & 6.1 & Glucose & 550 & 570 & 4.5 & 0 \\
Dog 7... & 17 & 11.4 & Glucose & 500 & 542 & 6.0 & 0 \\
Monkey 2 & 8 & 2.8 & Glucose & 250 & 228 & 3.7 & 0 \\
Monkey 3 & 9 & 6.5 & Glucose & 430 & 400 & 3.0 & 0 \\
Rabbit 3. & 18 & 2.5 & Glucose & 250 & 260 & 4.0 & 30 \\
Rabbit 4. & 14 & 2.0 & Glucose & 200 & 186 & 4.0 & 0 \\
Rabbit 5. & 15 & 3.0 & Glucose & 275 & 240 & 4.0 & 0 \\
Rabbit 9. & 16 & 2.6 & NaCl & 260 & 250 & 4.2 & 8 \\
Rabbit 10 & 17 & 2.6 & NaCl & 260 & 225 & 4.2 & 5 \\
Rabbit 11 & 18 & 3.8 & NaCl & 370 & 415 & 4.0 & 5 \\
Rabbit 12 & 19 & 2.9 & NaCl & 280 & 255 & 4.5 & 0 \\
Rabbit 13 & 20 & 3.4 & NaCl & 330 & 310 & 4.0 & 5 \\
& & & & & & & \\
\hline
\end{tabular}

used in the experiments. The data show that four to six hours after the injection of either a five per cent solution of glucose or a 1.8 per cent solution of sodium chloride into the peritoneal cavity, the amount of fluid remaining is approximately that injected. In both the "glucose" and "saline" experiments the changes in the total amount of peritoneal fluid amounted to an increase or decrease of less than ten per cent of 
the amount injected. Since the amount of fluid injected was ten per cent of the body weight and since total body water is about seventy per cent of the body weight, the experiments would change available body water by less than 1.5 per cent. Because blood plasma, interstitial fluid and intracellular fluid are all in osmotic equilibrium, the effects of this change in body water will be distributed throughout all body fluids and be of minor importance in explaining changes found in the blood. In other words the chief changes produced in "the glucose" experiments are brought about by withdrawal of extracellular electrolyte and the chief changes of the "saline" experiments are the result of the increase in extracellular electrolyte $(\mathrm{NaCl})$.

The preponderant effect of loss or gain of sodium and chloride becomes apparent when one considers the losses or gains of these ions in relation to their total amounts in normal animals. The approximate losses of chloride and sodium in the "glucose" experiments may be estimated by multiplying the original volumes (or the final volume when this was determined) by the final concentrations of these ions in the peritoneal fluid. These calculated losses of chloride and sodium have been compared to the total amounts of chloride and sodium found in a normal dog, a normal monkey and two normal rabbits (unpublished data from this laboratory). In the " glucose" experiments the losses of chloride are about 25 per cent of total body chloride; the losses of sodium, about 20 per cent of total body sodium. In the "saline" experiments the effective increases in body sodium and chloride are more uncertain, especially in those animals excreting considerable quantities of urine. Neglecting excretion in the urine which was negligible in most of the experiments, similar calculations show that the increases in body chloride were about 50 per cent of total body chloride and the increases in sodium, about 30 per cent.

It was not deemed necessary to sacrifice dogs and monkeys in order to determine the amount of fluid remaining in the peritoneal cavity after the injection of 1.8 per solution of sodium chloride since the behavior of the various animals was similar and the appearance of the abdomen and the ease with which fluid could be withdrawn from the peritoneal cavity was the same in the "saline" and "glucose" experiments.

\section{B. Clinical aspects of animals subjected to re- moval of extracellular electrolyte with little alteration in total body water}

Following the intraperitoneal injection of glucose solutions, the animals suffered no local signs of pain or irritation. However, in all animals ( 8 dogs, 5 rabbits and 5 monkeys) signs of mild to severe dehydration developed which were comparable to those observed in dehydrated patients. The tongue and mucous membranes were dry; the skin showed loss of turgor; the animals became languid and looked sick. In the monkeys and rabbits greyish pallor such as is seen in "alimentary intoxication" could be distinguished. In about 24 hours the animals recovered completely.

Following the injection of isotonic glucose, no urine was passed by any of the animals during the periods of experimental observation which were four to six hours. In view of the clinical evidences of dehydration it was interesting to note that the animals were not thirsty. Autopsies on the animals listed in Table I confirmed the dryness of the mucous membranes, for only $5 \mathrm{cc}$. of mucoid material could be recovered from the stomach and small intestines in the dogs and monkeys. The small intestines of the rabbits contained little fluid but, as is the rule in this species, the stomach and colon were filled with considerable material which, however, was not very moist.

\section{Changes in the blood in the "glucose" experi- ments}

Data which concern the distribution of water in serum and erythrocytes are given for representative experiments in Table II. As was pointed out previously, the various data may be regarded as exemplifying the changes produced by the losses of 'extracellular electrolyte with little alteration in body water.

In all experiments the proportions of red cells in blood and the concentrations of serum proteins were increased. The increases in the proportion of red cells were considerable. If one take no account of the blood withdrawn for analyses, one may calculate the apparent loss of plasma which would produce the given change in the proportion of erythrocytes. Because loss of blood tends to be replaced by interstitial fluid, the calculation probably underestimates the diminution of plasma 
TABLE II

Changes in the blood following intraperitoneal injection of 5 per cent glucose

\begin{tabular}{|c|c|c|c|c|c|c|c|c|c|c|c|c|c|}
\hline Animal & $\begin{array}{c}\text { Experi- } \\
\text { ment } \\
\text { num- } \\
\text { ber }\end{array}$ & Weight & $\begin{array}{l}\text { Fluid } \\
\text { in- } \\
\text { jected }\end{array}$ & $\begin{array}{c}\text { Time } \\
\text { elapsed }\end{array}$ & $\begin{array}{c}\text { Cell } \\
\text { volume }\end{array}$ & $\begin{array}{l}\text { Serum } \\
\text { protein }\end{array}$ & $\begin{array}{l}\text { Serum } \\
\text { water }\end{array}$ & $\begin{array}{c}\text { Serum } \\
\mathbf{N a}\end{array}$ & $\underset{\mathrm{Cl}}{\text { Serum }}$ & $\begin{array}{c}\text { Cell } \\
\text { water }\end{array}$ & $\begin{array}{c}\text { Cell } \\
\text { protein }\end{array}$ & $\begin{array}{c}\text { Peritoneal } \\
\mathrm{Na}\end{array}$ & $\begin{array}{l}\text { Peritoneal } \\
\mathrm{Cl}\end{array}$ \\
\hline & & kgm. & $c c$ & hours & per cent & per cent & per cent & $\begin{array}{l}\text { m. Eq. } \\
\text { per } L \text {. }\end{array}$ & $\begin{array}{l}\text { m. Eq. } \\
\text { per L. }\end{array}$ & per cent & per cent & $\begin{array}{l}\text { m. Eq. } \\
\operatorname{per} L \text {. }\end{array}$ & $\begin{array}{l}\text { m. Eq. } \\
\text { per } L \text {. }\end{array}$ \\
\hline Dog 3.. & 4 & 6.0 & 500 & $\begin{array}{l}0.0 \\
4.5\end{array}$ & $\begin{array}{l}39.6 \\
52.2\end{array}$ & $\begin{array}{l}4.8 \\
5.8\end{array}$ & & $\begin{array}{l}143.3 \\
130.7\end{array}$ & $\begin{array}{r}112.4 \\
92.6\end{array}$ & & $\begin{array}{l}33.6 \\
28.9\end{array}$ & 114.3 & 96.2 \\
\hline Dog $1 .$. & 1 & 6.4 & 500 & $\begin{array}{l}0.0 \\
6.0\end{array}$ & $\begin{array}{l}48.7 \\
57.2\end{array}$ & $\begin{array}{l}6.4 \\
8.4\end{array}$ & & $\begin{array}{l}147.3 \\
132.5\end{array}$ & $\begin{array}{r}106.1 \\
86.8\end{array}$ & & $\begin{array}{l}32.8 \\
30.3\end{array}$ & 115.0 & 91.1 \\
\hline $\operatorname{Dog} 3 \ldots$ & 5 & 5.5 & 500 & $\begin{array}{l}0.0 \\
4.5\end{array}$ & $\begin{array}{l}34.0 \\
44.8\end{array}$ & $\begin{array}{l}5.7 \\
6.9\end{array}$ & & $\begin{array}{l}144.1 \\
124.4\end{array}$ & $\begin{array}{r}112.6 \\
91.8\end{array}$ & - & $\begin{array}{l}31.9 \\
29.1\end{array}$ & 107.8 & 91.8 \\
\hline Dog 3 . & 7 & 6.1 & 550 & $\begin{array}{l}0.0 \\
4.0\end{array}$ & $\begin{array}{l}44.9 \\
54.4\end{array}$ & $\begin{array}{l}5.8 \\
8.0\end{array}$ & $\begin{array}{l}92.4 \\
90.3\end{array}$ & $\begin{array}{l}147.5 \\
131.7\end{array}$ & $\begin{array}{r}111.1 \\
91.2\end{array}$ & $\begin{array}{l}74.4 \\
75.4\end{array}$ & $\begin{array}{l}30.3 \\
28.6\end{array}$ & 105.3 & 88.2 \\
\hline Monkey 4 . . & 10 & 3.8 & 400 & $\begin{array}{l}0.0 \\
4.5\end{array}$ & $\begin{array}{l}43.7 \\
55.2\end{array}$ & $\begin{array}{l}6.8 \\
8.0\end{array}$ & $\begin{array}{l}90.9 \\
88.9\end{array}$ & $\begin{array}{l}144.6 \\
125.2\end{array}$ & $\begin{array}{r}104.5 \\
82.9\end{array}$ & $\begin{array}{l}76.7 \\
78.8\end{array}$ & $\begin{array}{l}29.0 \\
25.9\end{array}$ & & \\
\hline Monkey 4 . . & 11 & 3.5 & 300 & $\begin{array}{l}0.0 \\
4.0\end{array}$ & $\begin{array}{l}41.8 \\
46.8\end{array}$ & $\begin{array}{l}7.7 \\
8.3\end{array}$ & $\begin{array}{l}90.6 \\
89.8\end{array}$ & $\begin{array}{l}150.2 \\
131.4\end{array}$ & $\begin{array}{r}108.5 \\
90.4\end{array}$ & $\begin{array}{l}75.9 \\
76.5\end{array}$ & $\begin{array}{l}30.8 \\
28.2\end{array}$ & 125.8 & 99.4 \\
\hline Monkey 2. . & 8 & 2.8 & 250 & $\begin{array}{l}0.0 \\
3.5\end{array}$ & $\begin{array}{l}47.0 \\
58.5\end{array}$ & $\begin{array}{l}7.4 \\
9.5\end{array}$ & $\begin{array}{l}90.8 \\
88.2\end{array}$ & $\begin{array}{l}165.9 \\
145.3\end{array}$ & $\begin{array}{r}109.3 \\
96.2\end{array}$ & $\begin{array}{l}75.4 \\
76.5\end{array}$ & $\begin{array}{l}29.7 \\
28.9\end{array}$ & 92.9 & 75.6 \\
\hline Monkey 3 . . & 9 & 6.5 & 430 & $\begin{array}{l}0.0 \\
4.0\end{array}$ & $\begin{array}{l}50.0 \\
55.0\end{array}$ & $\begin{array}{l}7.5 \\
8.6\end{array}$ & $\begin{array}{l}90.6 \\
89.7\end{array}$ & $\begin{array}{l}154.5 \\
133.5\end{array}$ & $\begin{array}{r}110.1 \\
92.3\end{array}$ & $\begin{array}{l}76.4 \\
76.5\end{array}$ & $\begin{array}{l}28.5 \\
28.9\end{array}$ & 125.1 & 98.8 \\
\hline Rabbit $4 \ldots$ & 14 & 2.0 & 200 & $\begin{array}{l}0.0 \\
4.0\end{array}$ & $\begin{array}{l}35.5 \\
38.3\end{array}$ & $\begin{array}{l}6.1 \\
6.8\end{array}$ & $\begin{array}{l}92.5 \\
91.8\end{array}$ & $\begin{array}{l}137.5 \\
119.3\end{array}$ & $\begin{array}{l}95.4 \\
85.3\end{array}$ & $\begin{array}{l}76.3 \\
79.4\end{array}$ & $\begin{array}{l}29.6 \\
25.9\end{array}$ & 98.4 & 78.7 \\
\hline
\end{tabular}

volume which would otherwise have been produced by the loss of extracellular electrolytes. Roughly, by this calculation, the losses of plasma volume varied from 8 to 27 per cent of the total blood volume, or 18 to 49 per cent of the plasma volume. Similar calculations of the apparent losses of plasma water from the changes in concentration of serum proteins gave values roughly agreeing with those calculated from the changes in the proportion of red cells. Although changes in plasma volume are not the only factors affecting the concentration of cells in blood or proteins in serum, in experiments of short duration, changes of the magnitude shown in Table II could hardly occur without being due chiefly to losses of water from plasma.

The water of red cells increased as is evidenced by reductions in the concentration of cell proteins. Reductions in concentration of cell proteins occurred in all experiments except in the case of Monkey 3, Experiment 9, when the changes were so slight as to be within the error of the methods. The increases in erythrocytic water amounted to 1.4 to 7.3 per cent of the original cellular water.
Since total body water changed relatively little, this water was presumably derived from extracellular spaces.

In all cases considerable reductions were found in the concentrations of chloride and sodium in the serum. It is obvious that these reductions were chiefly brought about by migration of sodium and chloride into the peritoneal cavity.

D. Clinical aspects of animals subjected to increase of extracellular electrolyte with little alteration of body water

The intraperitoneal injection of 1.8 per cent solution of sodium chloride produced few clinical symptoms. The animals retained their appetites and did not look ill although two dogs vomited. They became thirsty but no loss of skin turgor occurred. Grossly the rabbits which were examined postmortem revealed nothing abnormal except the fluid in the peritoneal cavity. No ill effects were noted after 24 hours.

In three of the experiments on dogs a definite diuresis occurred, resulting in the loss of about 25 per cent of the fluid injected (see Table III). In 
TABLE III

Changes in the blood following intraperitoneal injection of 1.8 per cent $\mathrm{NaCl}$

\begin{tabular}{|c|c|c|c|c|c|c|c|c|c|c|c|c|c|c|c|c|}
\hline \multirow{2}{*}{ Animal } & \multirow{2}{*}{$\begin{array}{c}\text { Experi- } \\
\text { ment } \\
\text { num- } \\
\text { ber }\end{array}$} & \multirow{2}{*}{ Weight } & \multirow{2}{*}{$\begin{array}{c}\text { Fluid } \\
\text { in- } \\
\text { jected }\end{array}$} & \multirow{2}{*}{$\begin{array}{c}\text { Time } \\
\text { elapsed }\end{array}$} & \multirow{2}{*}{$\begin{array}{c}\text { Cell } \\
\text { volume }\end{array}$} & \multirow{2}{*}{$\begin{array}{l}\text { Serum } \\
\text { protein }\end{array}$} & \multirow{2}{*}{$\begin{array}{l}\text { Serum } \\
\text { water }\end{array}$} & \multirow{2}{*}{$\begin{array}{c}\text { Serum } \\
\mathrm{Na}\end{array}$} & \multirow{2}{*}{$\underset{\mathrm{Cl}}{\text { Serum }}$} & \multirow{2}{*}{$\begin{array}{c}\text { Cell } \\
\text { water }\end{array}$} & \multirow{2}{*}{$\mid \begin{array}{c}\text { Cell } \\
\text { protein }\end{array}$} & \multicolumn{2}{|c|}{ Peritoneal } & \multicolumn{3}{|c|}{ Urine } \\
\hline & & & & & & & & & & & & $\mathrm{Na}$ & $\mathrm{Cl}$ & $\begin{array}{l}\text { Vol- } \\
\text { ume }\end{array}$ & $\mathrm{Na}$ & $\mathrm{Cl}$ \\
\hline Dog 3. & 4 & $\begin{array}{r}\mathrm{kgm} . \\
6.5\end{array}$ & $\begin{array}{l}c c . \\
600\end{array}$ & \begin{tabular}{|c|} 
hours \\
\\
0.0 \\
4.5
\end{tabular} & $\begin{array}{c}\text { per cent } \\
\\
45.1 \\
38.5\end{array}$ & $\begin{array}{c}\text { per cent } \\
6.7 \\
6.1\end{array}$ & per cent & $\begin{array}{c}m . E q . \\
\text { per } L . \\
140.1 \\
157.6\end{array}$ & \begin{tabular}{|c} 
m. Eq. \\
per $L$. \\
108.2 \\
132.0
\end{tabular} & per cent & \begin{tabular}{|c|} 
per cent \\
31.6 \\
32.6
\end{tabular} & 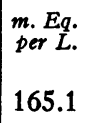 & $\begin{array}{c}\begin{array}{c}m . E q . \\
\operatorname{per} L . \\
160.0\end{array} \\
\end{array}$ & $c c$. & $\begin{array}{c}\underset{\operatorname{mer} L}{\operatorname{Eg}} . \\
- \\
-\end{array}$ & $\begin{array}{c}\begin{array}{c}\text { m.Eq. } \\
\text { per } L .\end{array} \\
-\end{array}$ \\
\hline $\operatorname{Dog} 3 \ldots$ & 1 & 5.3 & 500 & $\begin{array}{l}0.0 \\
4.5\end{array}$ & $\begin{array}{l}38.5 \\
35.0\end{array}$ & $\begin{array}{l}6.0 \\
5.6\end{array}$ & & $\begin{array}{l}146.2 \\
162.7\end{array}$ & \begin{tabular}{|l|}
110.8 \\
131.4
\end{tabular} & & $\begin{array}{l}32.7 \\
34.2\end{array}$ & 168.8 & 153.0 & 0 & - & - \\
\hline $\operatorname{Dog} 4 \ldots$ & 5 & 11.6 & 1000 & $\begin{array}{l}0.0 \\
5.0\end{array}$ & $\begin{array}{l}64.4 \\
56.1\end{array}$ & $\begin{array}{l}5.9 \\
5.9\end{array}$ & & $\begin{array}{l}142.0 \\
152.9\end{array}$ & \begin{tabular}{|l|}
111.0 \\
135.0
\end{tabular} & & $\begin{array}{l}31.8 \\
32.9\end{array}$ & & 156.0 & 360 & 218 & 206 \\
\hline Dog $4 \ldots$ & 3 & 11.2 & 1000 & $\begin{array}{l}0.0 \\
4.0\end{array}$ & $\begin{array}{l}37.5 \\
34.8\end{array}$ & $\begin{array}{l}6.2 \\
6.3\end{array}$ & & $\begin{array}{l}147.1 \\
161.4\end{array}$ & \begin{tabular}{|l|}
112.2 \\
130.6
\end{tabular} & & $\begin{array}{l}34.1 \\
34.2\end{array}$ & & & 240 & - & 380 \\
\hline Dog 5 & 8 & 7.0 & 700 & $\begin{array}{l}0.0 \\
4.0\end{array}$ & $\begin{array}{l}48.1 \\
45.3\end{array}$ & $\begin{array}{l}6.2 \\
6.2\end{array}$ & $\begin{array}{l}91.9 \\
92.1\end{array}$ & \begin{tabular}{|l|}
145.8 \\
161.1
\end{tabular} & \begin{tabular}{|l|}
111.6 \\
129.8
\end{tabular} & $\begin{array}{l}74.3 \\
74.2\end{array}$ & $\begin{array}{l}31.7 \\
32.7\end{array}$ & 166.6 & 150.1 & 180 & 319 & 339 \\
\hline Monkey 4 & 10 & 3.7 & 350 & $\begin{array}{l}0.0 \\
4.0\end{array}$ & $\begin{array}{l}36.0 \\
27.4\end{array}$ & $\begin{array}{l}7.4 \\
6.1\end{array}$ & $\begin{array}{l}90.7 \\
91.9\end{array}$ & \begin{tabular}{|l}
148.2 \\
165.1
\end{tabular} & \begin{tabular}{|l|}
107.4 \\
130.7
\end{tabular} & $\begin{array}{l}76.9 \\
74.5\end{array}$ & $\begin{array}{l}27.2 \\
29.4\end{array}$ & & & $\pm^{*}$ & & \\
\hline Monkey 3 & 9 & 5.8 & 425 & $\begin{array}{l}0.0 \\
5.0\end{array}$ & \begin{tabular}{|l|}
46.2 \\
40.2
\end{tabular} & $\begin{array}{l}7.6 \\
7.3\end{array}$ & $\begin{array}{l}90.6 \\
91.1\end{array}$ & \begin{tabular}{|l}
147.2 \\
163.9
\end{tabular} & \begin{tabular}{|l|}
104.9 \\
125.0
\end{tabular} & $\begin{array}{l}76.2 \\
74.0\end{array}$ & $\begin{array}{l}29.4 \\
31.9\end{array}$ & 164.7 & 140.9 & \pm & & \\
\hline Monkey 5 & 11 & 2.6 & 260 & $\begin{array}{l}0.0 \\
4.5\end{array}$ & $\begin{array}{l}41.9 \\
35.0\end{array}$ & $\begin{array}{l}7.5 \\
6.5\end{array}$ & $\begin{array}{l}91.1 \\
91.9\end{array}$ & \begin{tabular}{|l|}
144.9 \\
169.4
\end{tabular} & \begin{tabular}{|l|}
107.5 \\
142.1
\end{tabular} & $\begin{array}{l}75.0 \\
73.4\end{array}$ & $\begin{array}{l}32.5 \\
33.6\end{array}$ & & & \pm & & \\
\hline Monkey 5 & 12 & 2.5 & 225 & $\begin{array}{l}0.0 \\
3.8\end{array}$ & $\begin{array}{l}38.8 \\
29.3\end{array}$ & $\begin{array}{l}6.9 \\
6.1\end{array}$ & $\begin{array}{l}91.3 \\
91.4\end{array}$ & \begin{tabular}{|l|}
147.0 \\
165.3
\end{tabular} & \begin{tabular}{|l|}
107.4 \\
132.2
\end{tabular} & $\begin{array}{l}75.3 \\
74.5\end{array}$ & $\begin{array}{l}31.7 \\
34.8\end{array}$ & & & \pm & & \\
\hline Rabbit 7 .. & 14 & 2.5 & 250 & $\begin{array}{l}0.0 \\
4.0\end{array}$ & \begin{tabular}{|l|}
30.8 \\
26.5
\end{tabular} & $\begin{array}{l}4.9 \\
4.4\end{array}$ & $\begin{array}{l}93.7 \\
94.3\end{array}$ & \begin{tabular}{|l|}
138.7 \\
152.0
\end{tabular} & \begin{tabular}{|l|}
103.3 \\
121.8
\end{tabular} & $\begin{array}{l}74.7 \\
73.3\end{array}$ & $\begin{array}{l}31.9 \\
32.6\end{array}$ & & & \pm & & \\
\hline Rabbit $8 \ldots$ & 15 & 1.9 & 180 & $\begin{array}{l}0.0 \\
4.0\end{array}$ & $\begin{array}{l}40.4 \\
27.0\end{array}$ & $\begin{array}{l}7.7 \\
6.2\end{array}$ & $\begin{array}{l}90.8 \\
92.2\end{array}$ & $\begin{array}{l}152.8 \\
175.6\end{array}$ & \begin{tabular}{|l|}
123.1 \\
154.0
\end{tabular} & $\begin{array}{l}76.3 \\
74.8\end{array}$ & $\begin{array}{l}29.9 \\
31.5\end{array}$ & 182.4 & 172.1 & \pm & & \\
\hline
\end{tabular}

${ }^{*} \pm$ indicates less than $5 \mathrm{cc}$. of urine.

these cases the urine contained 200 to 350 milliequivalents of sodium and chloride per liter. In the other experiments practically no urine was passed during the first 4 to 6 hours.

\section{E. Changes in the blood in the "saline" experiments}

The results of the examination of the blood in representative experiments are given in Table III. As was pointed out previously, the various changes may be regarded as exemplifying the alterations produced by an increase in extracellular electrolyte with little alteration in total body water. In both experiments on Dog 3 and in all experiments on rabbits and monkeys, only minimal amounts of urine were excreted. Since in both experiments on Dog 4 and the one on Dog 5, about one fourth of the salt and water injected into the peritoneal cavity was recovered in the urine, these experiments gave less striking but qualitatively similar changes.

In Dog 3 and in the rabbits and monkeys the concentration of serum protein and the proportion of red cells in blood decreased. The apparent increases in plasma volume were 16 to 52 per cent when calculated from the changes in the proportion of red cells in blood while the apparent increases were 4 to 24 per cent when calculated from the changes in concentration of serum proteins. In each experiment the former calculation led to a greater value than the latter. However, so many factors may influence the concentration of serum proteins or the proportion of red cells in blood that a close correlation is unlikely. The changes are sufficiently great to indicate considerable increases in plasma volume. 
The concentrations of proteins in the red cells increased owing to losses of erythrocytic water. The losses of cellular water varied from 2 to 7 per cent of the original water. Because body water remained relatively constant, the water which left the red cells presumably migrated to the extracellular spaces.

In Dogs 4 and 5, the results were much the same as in the other experiments, if consideration be given the large amount of salt and water excreted. The changes in the proportion of red cells indicate considerable increases in plasma volume. However, for some reason which is not apparent, the concentrations of serum proteins did not change. The proteins of the red cells became concentrated owing to losses of cellular water, except in Dog 4, Experiment 8. The changes in serum sodium and chloride in Dogs 4 and 5 are of the same order of magnitude as those of the other experiments.

In all cases considerable increases in the concentration of chloride and sodium in serum occurred owing to migration of these ions from the fluid injected into the peritoneal cavity. The apparent means which the body uses to maintain osmotic equilibrium in both types of experiment will be brought out in the discussion.

\section{DISCUSSION}

Since the principal phenomena exhibited by the experiments must fit into the concepts of the physiological behavior of water, a tentative description of the factors affecting the distribution of water in the body will be given. Almost seven-tenths of the body is made up of water which moves between intracellular and extracellular spaces in such a manner as to maintain osmotic equilibrium between the fluid of the cells and that in the extracellular spaces. Since about nine-tenths of the osmotic pressure of body fluids is maintained by electrolytes, the distribution of body water is largely determined by the distribution of electrolytes. Furthermore, as the concentration of anions equals the concentration of cations, the approximate osmotic relations are given by the concentrations of the total base in milliequivalents per liter of water. Because the preponderant bases are the univalent ions, sodium and potassium, the concentrations of these cations determines roughly the osmotic pressure. One may, therefore, surmise that the factors controlling the distribution of sodium and potassium also govern the distribution of water.

From analyses of blood plasma, lymph, edema fluid and cerebrospinal fluid it is fairly well established that all extracellular fluids have approximately the composition of plasma, except that little protein is present in the extracellular fluids outside of the vascular system. The actual amount of extracellular fluid is unknown, but analyses of muscles (9) and whole bodies (10, 11) indicate that about two-tenths of the body weight must be due to extracellular fluid. This estimate is obtained by assuming all but negligible quantities of sodium and chloride are extracellular and that their concentrations in extracellular fluids are essentially those of blood plasma when expressed in concentrations per kilogram of water. Assuming this to be true, about five-tenths of the body weight is made up of intracellular water. The chemical composition of intracellular fluid is not known, but from analyses of red cells (12, $13,14)$, muscles (9) and whole bodies $(10,11)$, one may surmise that the chief anions are proteins and phosphate (chiefly organic) and the chief cation, potassium. This particular distribution of ions with sodium and chloride ${ }^{1}$ on one side of the cellular membrane and potassium and phosphate on the other is usually assumed to indicate relative impermeability of cellular membranes to these ions.

The probable changes in distribution of body water which fit in with the concepts briefly outlined above can most readily be brought out with the aid of a diagram (Figure 1). On the ordinate, the concentrations of electrolyte are indicated in milliequivalents per liter of water, while on the abscissa, the volumes of body water are represented in liters. The areas bounded by these lines, therefore, represent the total amount of electrolyte in intracellular and extracellular compartments. The original distribution of body water is given by the continuous lines; the distribution of body water after removal of 100 milliequivalents of extracellular electrolyte is represented by the lines which are made up of dots

\footnotetext{
1 The chloride of the erythrocytes is apparently an exception to the rule that intracellular fluids contain little or no chloride.
} 


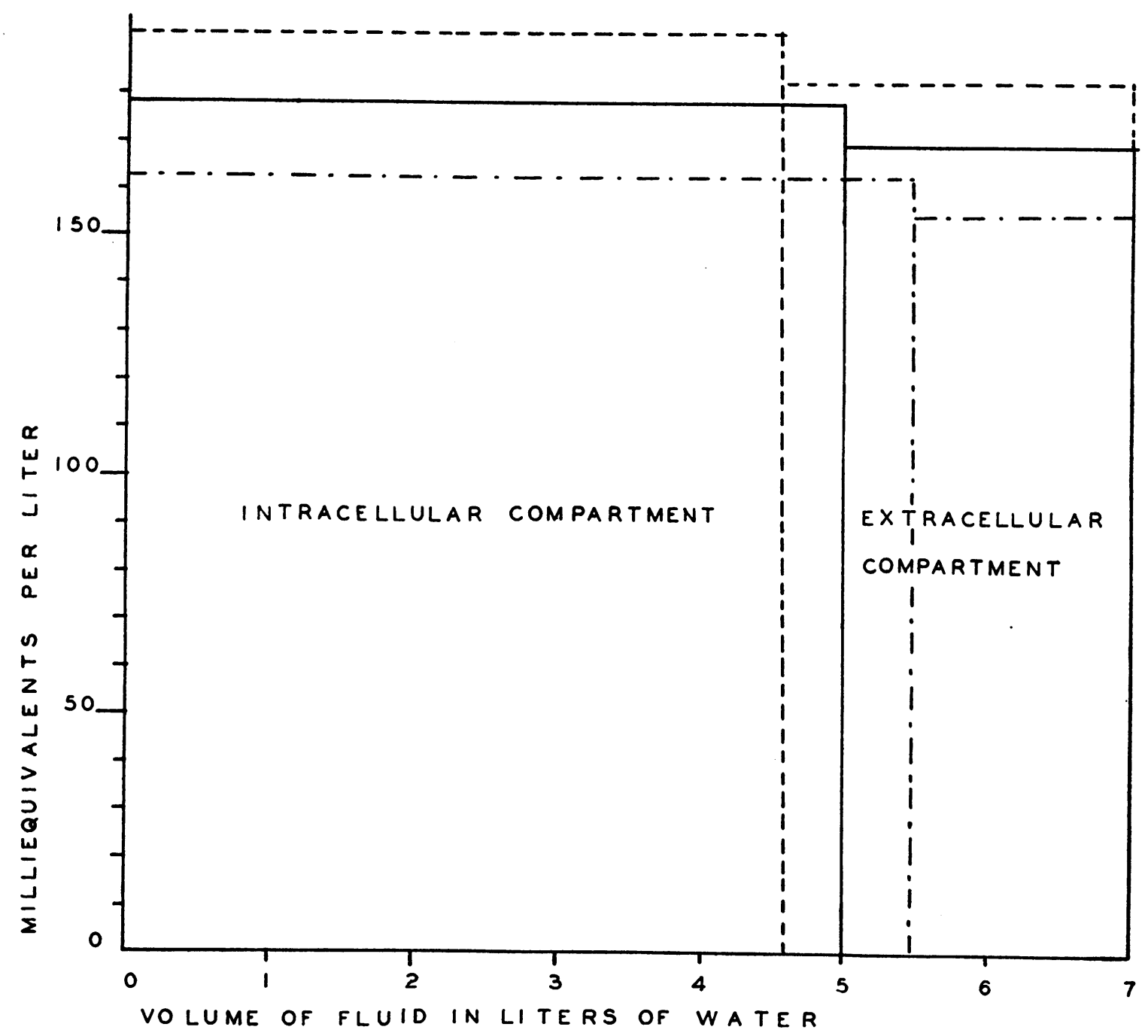

Fig. 1. Diagrammatic Representation of the Distribution of Body Water and Electrolyte.

The areas bounded by the lines representing volume and concentration indicate the total amount of intracellular or extracellular electrolyte. The solid lines give the distribution under normal conditions; the lines made up of dots and dashes indicate the distribution after removal of $100 \mathrm{~m}$. Eq. of extracellular electrolyte; the lines made up of dashes represent the distribution after addition of $100 \mathrm{~m}$. Eq. of extracellular electrolyte.

and dashes; the distribution of body water after addition of 100 milliequivalents of extracellular electrolyte is illustrated by the lines made up of dashes. Since by assumption the total amount of intracellular electrolyte does not change, the three areas representing intracellular electrolyte are equal. However, in order to maintain osmotic equilibrium between the intracellular fluid containing a fixed amount of electrolyte and the extracellular fluid containing variable amounts of electrolyte, the volume of intracellular water and the concentration of intracellular electrolyte must vary as indicated in the diagram. The relation of the changes in amount of extracellular electrolyte to the total body fluid is represented in the diagram in quantities and concentrations comparable to those which the experiments present.

The areas in the diagram representing the shift in water accompanying loss of extracellular electrolyte indicate the probable changes occurring in the "glucose" experiments. This part of the diagram will be discussed first together with the 
assumptions on which the diagram is based and the reasons for making these assumptions.

Conceivably osmotic equilibrium between intracellular and extracellular fluids might be brought about by transfer of water across cellular membranes, by transfer of ions across cellular membranes, or by both processes. However, previous work $(12,13)$ and data obtained in these experiments which will be discussed more fully elsewhere (14) indicate that transfer of water is the chief means of adjusting the osmotic equilibrium between plasma and erythrocytes. Since most cellular membranes are likewise commonly regarded as relatively impermeable to cations, shift of water across cellular membranes is probably the chief means of maintaining osmotic equilibrium between intracellular and extracellular fluids. The diagram represents transfer of water as the sole means of adjusting osmotic relationships.

The experimental observations indicate that shift of water across cellular membranes is probably the chief means of maintaining osmotic equilibrium between body fluids. As was pointed out previously, in the "glucose" experiments the changes in concentration of proteins in serum and red cells in blood indicate apparent losses of plasma volume of 18 to 49 per cent of the original volumes. Loss of skin turgor signifies diminution of extracellular fluids elsewhere than in the blood. The symptoms and signs of dehydration are those which one is accustomed to associate with loss of extracellular fluid. Furthermore, the losses of sodium and chloride are equal to about one fourth of the amounts of these ions in normal animals. If the sodium and chloride remaining in the extracellular fluid had not been concentrated by transfer of water from extracellular to intracellular spaces, the concentrations of serum sodium and chloride would have shown greater reductions than those found. Indication of transfer of extracellular water is given directly by the decreases in concentration of erythrocytic proteins. The "glucose" experiments as a whole fit in with the concepts represented in the diagram and indicate that loss of extracellular electrolyte with little or no change in body water leads to hydration of intracellular fluids and dehydration of extracellular fluids.

In the diagram the loss of extracellular electro- lyte produces a ten per cent increase in intracellular water and a twenty-five per cent decrease in extracellular fluids. With a given loss of extracellular electrolyte accompanied by a disproportionate loss of water, or, as in the "glucose" experiments by little change in body water, the magnitude of the reduction in concentration of extracellular electrolyte will be dependent, not on the volume of extracellular fluid but rather on total volume of body water. ${ }^{2}$ This deduction follows from the fact that the change in osmotic pressure produced by loss of extracellular electrolyte must be equalized throughout all body fluids. Since this adjustment apparently takes place chiefly by shift of water from extracellular to intracellular compartments, the magnitude of this transfer of water will be dependent upon the relation of the volume of extracellular water to total body water. It is, therefore, apparent that a value for the proportion of body fluid in extracellular spaces is a necessary factor in predicting alterations in the distribution of body water under varying conditions.

The observations in the "saline" experiments likewise fit in with the concepts expressed in the diagram (Figure 1) showing the changes produced by increase in the amount of extracellular electrolyte without alteration in total body water. In this case, since the increase in extracellular electrolyte augments the osmotic pressure of this fluid, water is attracted from the cells to the extracellular spaces.

In the "saline" experiments, the effective increase in sodium and chloride in the extracellular fluid is uncertain, especially when diuresis occurred. However, in general, the changes in concentration of chloride and sodium are of an order

2 This relationship for constant total body water and when the only loss of base is loss of $\mathrm{Na}$ from extracellular water, may be expressed by the following formula :

$$
[\mathrm{Na}]_{1} \mathrm{~V}-(\mathrm{Na})_{\mathrm{p}}=[\mathrm{Na}]_{2} \mathrm{~V},
$$

where $[\mathrm{Na}]_{1}$ is the original concentration of sodium in serum water; $[\mathrm{Na}]_{2}$ is the second concentration of sodium in serum water; $(\mathrm{Na})_{\mathrm{p}}$ is the change in body sodium and $\mathrm{V}$ is the volume of body water in liters. The application of this formula to the data in the "glucose" experiments yields values for V (total body water) which fit in with the probable value for total body water, namely, about 70 per cent of total body weight. 
of magnitude that indicate that extracellular fluid must have been diluted with water obtained from the cells of the body. The changes in concentration of the proteins in erythrocytes indicate that these cells lost water as is also attested by the decreases in the water of the red cells. Increase in extracellular fluid is difficult to demonstrate because fairly large accumulations of interstitial fluid often give no signs. However, increases in plasma volume are indicated by the decreases in concentration of proteins in serum and of red cells in blood. In other words, the chief finding in the "saline" experiments fit in with the concepts of the diagram and indicate that increase in extracellular electrolyte with little change in body water produces hydration of extracellular fluids and dehydration of intracellular fluids.

It is interesting to note that no urine was excreted during the "glucose" experiments in spite of the reductions in concentration of electrolyte and the probable hydration of the cells. In the "saline" experiments, part of the excess of sodium and chloride in some instances was excreted so as to diminish the disturbances but in two of the experiments on dogs and all of those on rabbits and monkeys, little urine was formed during the period of observation. We have no satisfactory explanation of the reason why the kidneys failed to adjust electrolyte concentration.

Whatever facts about renal adjustment of water volume or electrolyte concentration are discovered, or whatever knowledge concerning permeability of cellular membranes and the actual volumes of the various types of body fluids is developed, the present experiments demonstrate that disturbances in the distribution of body water can occur and induce grave symptoms even when body water is little changed. In acute adrenal insufficiency in dogs $(15,16,17)$, a striking loss of sodium unaccompanied by a corresponding diminution of body water has been demonstrated. From a chemical point of view the changes in acute adrenal insufficiency and those produced by loss of extracellular electrolyte in the "glucose" experiments are quite similar. The explanation of the symptoms and chemical evidences of dehydration in adrenal insufficiency is probably also similar to that presented in this paper. After the present experiments were practically completed and the interpretation developed, Gilman (18) re- peated the essential features of our experiments and showed that a decrease in blood pressure and increase in susceptibility to the effects of hemorrhage occur with loss of extracellular electrolyte and little change in body water. Furthermore disturbances in the distribution as well as the amounts of body water probably occur as the result of disproportionate losses of water and electrolyte in diabetic coma, persistent vomiting, protracted diarrhea, heat stroke, etc. It is also worth noting that the temporary immobilization of extracellular electrolyte following therapeutic injecfion of solutions of glucose into the peritoneal cavity and subcutaneous tissues will have the same effect as that recorded in the "glucose" experiments.

Gamble, Ross and Tisdall (1) have pointed out that when the loss or gain of base is accompanied by proportionate changes in body water, the changes in the volumes of intracellular and extracellular fluids may be estimated from the concentrations of intracellular potassium and extracellular sodium. However, when the loss or gain of base is not accompanied by a proportionate change in body water such as occurs in pathological disorders accompanied by marked changes in the concentration of sodium in the serum, the estimation of the probable changes in the volumes of intracellular and extracellular fluid cannot be made without a knowledge of the ratio of intracellular potassium to extracellular sodium in the body.

Few reports give data which enable one to calculate the ratio of body potassium to body sodium. Katz (9) found the ratio in adult human muscle to be 2.37; Klose (10) found the ratio in the whole body of an infant to be 0.45 and Iob and Swanson (11), 0.52. In this laboratory (19) the ratio for a dog was 0.84 ; for a monkey, 1.22 and for two rabbits, 1.41 and 1.44. (The ratios are based on molecular concentrations.) In order to apply ratios derived from analyses of whole bodies, it is necessary to establish how nearly sodium is exclusively extracellular. Furthermore, the probable volume of extracellular fluid must be determined. In any case, it is misleading to speak of intracellular and extracellular water without bearing in mind that the water of the body may become either intracellular or extracellular, depending on the factors governing its distribution. 


\section{SUMMARY}

Experiments on dogs, rabbits and monkeys are described which induced (1) loss of extracellular electrolyte with little change in total body water and (2) increase in extracellular electrolyte with little change in total body water.

The loss of extracellular electrolyte with little change in body water induced symptoms and signs of dehydration. The concentrations of chloride and sodium in serum were reduced; the concentrations of proteins in serum and the proportions of red cells in blood increased; the concentrations of proteins in erythrocytes were reduced by increases in cellular water. These phenomena are probably referable to shift of extracellular water into body cells producing dehydration of extracellular fluids and hydration of intracellular fluids.

Increase in extracellular electrolyte with little change in total body water induced few symptoms except thirst. The concentrations of chloride and sodium in serum increased; the concentrations of proteins in serum and the proportion of red cells in blood decreased; the concentrations of proteins in erythrocytes increased owing to losses of cellular water. The probable explanation of these findings is shift of water from body cells into extracellular spaces producing dehydration of the cells and hydration of extracellular fluids.

The factors governing the distribution of body water are discussed.

\section{BIBLIOGRAPHY}

1. Gamble, J. L., Ross, G. S., Tisdall, F. F., The metabolism of fixed base during fasting. J. Biol. Chem., 1923, 57, 633.

2. Gamble, J. L., Blackfan, K. D., and Hamilton, B., A study of the diuretic action of acid-producing salts. J. Clin. Invest., 1925, 1, 359.

3. Atchley, D. W., Loeb, R. F., Richards, D. W., Jr., Benedict, E. M., and Driscoll, M. E., On diabetic acidosis. A detailed study of electrolyte balances following the withdrawal and reestablishment of insulin therapy. J. Clin. Invest., 1932, 12, 297.
4. Butler, A. M., McKhann, C. F., and Gamble, J. L., Intracellular fluid loss in diarrheal disease. J. Pediat., 1933, 3, 84.

5. Schechter, A. J., Cary, M. K., Carpentieri, A. L., and Darrow, D. C., Changes in composition of fluids injected into the peritoneal cavity. Am. J. Dis. Child., 1933, 46, 1015.

6. Peters, J. P., and Van Slyke, D. D., Quantitative Clinical Chemistry. Volume II. Methods. Williams \& Wilkins Co., Baltimore, 1932, p. 691.

7. Ibid., p. 736.

8. Ibid., p. 738.

9. Katz, J., Die mineralishen Bestandtheile des Muskelfleisches. Arch. f. d. ges. Physiol., 1896, 63, 1.

10. Klose, E., Zur Kenntniss der Körperzusammensetzung bei Ernährungsstörungen. Jahrb. f. Kinderh., 1914, 80, 154.

11. Iob, V., and Swanson, W. W., Mineral growth of the human fetus. Am. J. Dis. Child., 1934, 47, 302.

12. Kerr, S., Studies on the inorganic composition of blood. II. Changes in the potassium content of erythrocytes under certain experimental conditions. J. Biol. Chem., 1926, 67, 721.

13. Wakeman, A. M., Eisenman, A. J., and Peters, J. P., A study of human red blood cell permeability. J. Biol. Chem., 1927, 73, 567.

14. Yannet, H., and Darrow, D. C., The chemical changes in red cells accompanying changes in the concentration of plasma. (To be published.)

15. Loeb, R. F., Atchley, D. W., Benedict, E. M., and Leland, J., Electrolyte balance studies in adrenalectomized dogs with particular reference to the excretion of sodium. J. Exper. Med., 1933, 57, 775.

16. Harrop, G. A., Weinstein, A., Soffer, L. J., and Trescher, J. H., Studies on the suprarenal cortex. II. Metabolism, circulation and blood concentration during suprarenal insufficiency in the dog. J. Exper. Med., 1933, 58, 1.

17. Harrop, G. A., Soffer, L. J., Ellsworth, R., and Trescher, J. H., Studies on the suprarenal cortex. III. Plasma electrolytes and electrolyte excretion during suprarenal insufficiency in the dog. J. Exper. Med., 1933, 58, 17.

18. Gilman, A., Experimental sodium loss analogous to adrenal insufficiency: The resulting water shift and sensitivity to hemorrhage. Am. J. Physiol., 1934, 108, 662.

19. Unpublished data. 